\title{
KELEMBAGAAN TATANIAGA DAN FAKTOR YANG MEMPENGARUHI PETANI MANGGA MEMILIH SISTEM TEBASAN
}

\author{
Oleh \\ DINI ROCHDIANI, SARA RATNA QANTI, ZUMI SAIDAH \\ Departemen Sosial Ekonomi, Fakultas Pertanian, Universitas Padjadjaran \\ Jl. Raya Jatinangor Km.21 Sumedang-Indonesia \\ e-mail: dini.rochdiani@yahoo.co.id
}

\begin{abstract}
Abstrak
Seiring dengan terjadinya perubahan pada pertanian global saat ini telah memaksa petani mangga untuk memproduksi komoditas secara kontinyu dan bernilai tinggi (melalui berbagai upaya peningkatan nilai tambah). Salah satu upaya petani untuk memenuhi tujuan tersebut adalah dengan melakukan sistem tebasan. Penelitian ini bertujuan untuk mengetahui kelembagaan tataniaga petani mangga yang melakukan sistem tebasan dan mengidentifikasi faktor-faktor sosial ekonomi yang mempengaruhi petani mangga dalam melakukan sistem tebasan. Regresi multivariate digunakan sebagai alat analisis utama dalam mengolah data primer yang dikumpulkan melalui wawancara dengan 30 orang petani di Desa Pasirmuncang, Kecamatan Panyingkiran, Kabupaten Majalengka, Jawa Barat. Berdasarkan hasil analisis, diperoleh temuan penting, yaitu: (1) Dalam kelembagaan tataniaga mangga dengan sistem tebasan terdapat beberapa lembaga yang turut mengalirkan mangga dari produsen ke konsumen akhir, yaitu pedagang pengumpul tingkat Desa/Kecamatan, pedagang besar, para pedagang di pasar tradisional (lokal), eksportir, suplayer dan supermarket. Dalam pemasaran, buah mangga dikelompokan kedalam dua grade, yaitu grade $\mathrm{AB}$ merupakan grade utama, dipasarkan secara luas melalui empat saluran dan grade $\mathrm{C}$ (non grade) disalurkan ke pasar-pasar tradisional lokal melalui satu saluran pemasaran. Margin pemasaran paling besar terjadi pada saluran pemasaran yang pelaku-pelaku pasarnya melakukan penanganan hasil lebih intensif seperti suplayer dan supermarket dengan sasaran konsumen kelas ekonomi menengah ke atas. Pada seluruh saluran pemasaran grade AB, pedagang agen selalu mendapatkan marjin keuntungan paling besar, yaitu Rp.2.500,-/kg karena mereka merupakan pihak yang paling besar dalam pengeluaran biaya pemasaran dan juga resiko diakibatkan oleh fluktuasi harga jual mangga. Pengembangan produksi mangga masih perlu kerjasama dengan pelaku agribisnis, petani mendapatkan bantuan permodalan dan bimbingan praktek budidaya yang benai sementara pelaku agribisnis dapat memperoleh hasil mangga yang berkualitas, menciptakan peluang pasar baru dar mendirikan industri pengolah mangga segar untuk menjembatani kelebihan produksi pada waktu panen raya.Rata-rata petani mangga bersifat risk averse (penghindar risiko). (2) Secara serempak, faktor umur, pendidikan, pengalaman, luas lahan, biaya produksi, ketersediaan tenaga kerja dalam keluarga, kemampuan petani menanggung risiko, pendapatan petani dari mangga, dan pendapatan petani dari pekerjaan lainnya) mempengaruhi petani mangga untuk memilih sitem tebasan. Secara parsial, faktor umur petani dan faktor memiliki pekerjaan di luar usahatani mangga mempengaruhi secara negatif terhadap pemilihan sistem tebasan oleh petani mangga. Hasil penelitian menunjukkan bahwa implementasi sistem tebasan di mangga merupakan salah satu alternatif untuk peningkatan keuntungan dan pendapatan bagi petani mangga.
\end{abstract}

Kata kunci: tataniaga, mangga, petani, tebasan

\section{PENDAHULUAN}

Program dan usaha untuk mengkaitkan petani kecil pada pasar global dan modernisasi (linking farmer to market) menjadi sebuah semangat baru pada awal abad 21 yang mendominasi pemikiran para ekonom pembangunan dan lembaga-lembaga pembangunan (Worldbank, 2008). Dalam upaya mengkaitkan petani kecil pada pasar global, dibutuhkan suatu jaringan yang menghubungkan antara petani, pengolah (processors), pedagang (traders), pengecer (retailers) dalam suatu sistem agribisnis yang terintegrasi dan terkoordinasi.

Seiring dengan terjadinya perubahan pada pertanian global saat ini telah memaksa petani untuk memproduksi komoditas yang bernilai tinggi dan terlibat langsung dengan berbagai kegiatan untuk memperoleh nilai tambah (value-adding). Petani berperan secara lebih aktif melalui organisasi maupun dalam pengambilan tindakan kolektif untuk 


\section{AIMBAR \\ Agribisnis}

ISSN 2460-4321

Volume 1・Nomor 2・Januari 2016

memperoleh bagian (keuntungan) yang lebih besar di sepanjang jalur pemasaran (tataniaga).

Melihat hal tersebut, pemerintah mendorong petani untuk berorganisasi, namun pendekatan organisasi yang dijalankan merupakan bentuk intervensi pemerintah terhadap petani. Dari berbagai kebijakan yang telah dikeluarkan yang terkait dengan petani, maka gambaran yang muncul adalah berupa petani-petani kuat, berskala sedang dan luas, dan modern.

Kebanyakan dari petani tidak memperoleh manfaat dari kebijakan (regulasi) yang telah ditetapkan oleh pemangku kebijakan. Hal ini terjadi karena luputnya perhatian para pengambil kebijakan akan arti petani yang mana sebagian besar dari petani tersebut terdiri atas petani gurem (peasant), petani kecil (small farmer), dan buruh tani tanpa tanah (landless laborers) dengan ciri khasnya seperti penguasaan lahan kecil, berproduksi secara terbatas, namun lebih mandiri.

Begitu pula halnya dengan yang terjadi pada petani mangga yang pada umumnya merupakan petani gurem. Pada umumnya usahatani mangga belum dikelola secara intensif, akan tetapi lebih bersifat sebagai usaha sampingan (multicropping). Sehingga sering dijumpai di masyarakat, tanaman mangga tumbuh secara alamiah dan tanpa perawatan di pekarangan/tegal. Hal ini disebabkan oleh sifat tanaman mangga yang dapat tumbuh di dataran rendah maupun tinggi.

Berdasarkan beberapa hasil pengkajian dan penelitian agribisnis menunjukkan bahwa sistem pemasaran (tataniaga) dan perawatan mangga masih bersifat konvensional dan belum banyak berubah. Pada umumnya sistem pengusahaan mangga mulai dari tahap produksi hingga pemasaran hasil belum sepenuhnya memberikan insentif yang optimal kepada petani mangga. Berdasarkan kajian yang dilakukan oleh Natawidjaja (2012), menunjukan masih sangat sedikitnya persentase pohon mangga yang dibudidayakan dengan optimum. Pengelolaan pohon mangga secara intensif dan semi intensif hanya ditemukan dibeberapa sentra produksi utama, itupun masih dengan aplikasi teknologi yang seadanya. Selain itu, masa panen mangga sangat terkonsentrasi pada periode 2 bulan (November dan Desember) setiap tahun, sehingga harga mangga cenderung sangat rendah ditingkat petani pada periode puncak masa panen tersebut.

Kondisi produksi dan kualitas panen yang rendah membuat sebagian besar petani mangga memilih untuk menebas pohon mangga yang dimilikinya. Sistem tebasan ini sebenarnya sudah berlangsung sejak lama. Sebelumnya petani mangga hanya mengeksploitasi buah saja, tanpa ada kegiatan pemeliharaan. Namun seiring dengan perubahan dalam permintaan dan penawaran mangga, membuat banyaknya para pedagang dari luar daerah yang datang dan membuka peluang tataniaga mangga secara jual tebasan.

Pembelian saat panen, tebas di pohon, dan ijon merupakan cara pembelian yang banyak digunakan pedagang untuk mendapatkan mangga dari petani. Timbulnya sistem ijon ini sebagai akibat dari persaingan yang tajam antara pedagang yang jumlahnya cukup banyak. Selain itu juga tuntutan kebutuhan mendesak dari petani juga mendorong dilakukannya sistem tebas mangga. Pembelian secara tebas ini sudah dilakukan sejak buah masih pentil, bahkan sejak bakal bunganya mulai muncul. Keuntungan sistem tebas ini adalah petani tidak lagi mengeluarkan biaya untuk perawatan maupun biaya panen, karena bila dihitung biaya investasi pada mangga ini cukup besar terutama pada tanaman mangga yang terletak di kebunkebun yang berada di lereng bukit.

Berdasarkan uraian di atas, maka dalam penelitian menarik untuk dikaji mengenai gambaran (deskripsi) petani mangga yang melakukan sistem tebasan dan mengidentifikasi faktor-faktor sosial ekonomi yang mempengaruhi petani mangga dalam melakukan sistem tebasan.

\section{KERANGKA PEMIKIRAN}

Sistem tebasan merupakan pola tataniaga yang banyak dipilih petani dari pada non tebasan. Sistem tebasan merupakan bentuk perubahan kelembagaan dalam tataniaga mangga yang membuka peluang pasar yang lebih luas bagi para petani dengan harapan dapat meningkatkan produksi serta pendapatannya.

Ciri petani melakukan sistem tebasan yaitu adanya sistem sewa pohon, yang hal ini tidak dilakukan di non tebasan. Petani cenderung 


\section{Kelembagaan Tataniaga dan Faktor Yang Mempengaruhi Petani Mangga \\ Memilih Sistem Tebasan}

DINI ROCHDIANI, SARA RATNA QANTI, ZUMI SAIDAH

beranggapan bahwa sistem tebasan lebih baik dari non tebasan, karena petani menanggung risiko yang lebih kecil dibanding non tebasan. Risiko harga dapat diatasi dan diprediksi, karena periode waktu transaksi dilakukan di awal tahun yaitu pada bulan Januari saat pohon mangga selesai dipanen akhir tahun sebelumnya dan belum berbuah. Selain itu, beberapa petani mangga tersebut yang telah melakukan transaksi, ada yang diberikan bantuan modal oleh pembeli (penebas lain/pedagang pengumpul/bandar).

Bantuan modal ini menguntungkan kedua belah pihak, dari sisi petani tidak kesulitan mencari modal untuk usahatani mangga, dan dari sisi pembeli, dapat menekan risiko kegagalan produksi dan kualitas mangga yang akan dipasarkan kepada konsumen akhir. Bantuan modal tersebut berupa biaya pemeliharaan, seperti untuk pupuk, pestisida untuk pengendalian hama penyakit, serta penggunaan teknologi pertumbuhan mangga berupa pembelian nutrisi dan hormon tumbuh. Bantuan modal bertujuan agar mangga cepat berbuah dan mangga yang dihasilkan berproduksi tinggi serta berkualitas baik sesuai dengan permintaan pasar. Terdapat beberapa faktor sosial ekonomi yang mempengaruhi petani mangga dalam memilih sistem tebasan.

Faktor-faktor sosial antara lain umur, pendidikan, dan pengalaman petani mempengaruhi petani untuk melakukan sistem tebasan. Umur yang sudah tua dengan pendidikan rendah cenderung membuat petani tidak termotivasi intuk meningkatkan produksi dan mencari pasar yang lebih luas. Namun, kondisi tersebut bila diikuti dengan lamanya pengalaman petani berusahatani mangga serta intensitas petani dalam pemeliharaan tanaman dan juga penggunaan teknologi budidaya yang baik, maka faktor-faktor tersebut cenderung dapat memotivasi petani untuk berusahatani mangga dengan sistem tebasan. Faktor lainnya adalah adanya hubungan ikatan sosial antara petani dengan keluarga maupun pembeli yang juga dapat mempengaruhi petani memilih sistem tebasan. Hubungan ikatan petani dengan keluarganya bisa terjadi, seperti sistem tebasan telah dilakukan secara turun temurun dari keluarganya terdahulu. Selain itu, diduga terdapat hubungan ikatan petani dengan pembeli (penebas/pedagang/bandar) dalam bentuk komitmen dalam penjualan mangga seperti adanya bantuan modal dari pembeli kepada petani yang mengharuskan petani menjual mangganya kepada pembeli yang memberikan modal tersebut.

Faktor-faktor ekonomi yang mempengaruhi petani mangga melakukan sistem tebasan adalah luas lahan garapan yang digunakan untuk berusahatani mangga. Semakin luas lahan garapan yang ditanami mangga dengan sistem tebasan, maka cenderung biaya produksi yang dikeluarkan untuk usahatani mangga semakin besar. Biasanya biaya yang terbesar adalah tenaga kerja, sehingga jumlah ketersediaan tenaga kerja harus diperhitungkan secara efisien, karena semakin banyak tenaga kerja yang digunakan semakin besar upah tenaga kerja yang harus dikeluarkan. Namun, karena umumnya petani banyak menggunakan tenaga kerja keluarga dan upah tenaga kerja keluarga ini dianggap sebagai pendapatan petani beserta keluarganya, maka hal ini akan mengurangi biaya tenaga kerja. Diduga semakin besar jumlah ketersediaan tenaga kerja keluarga, semakin besar pendapatan petani yang diperoleh dari anggota keluarganya dan semakin memilih sistem tebasan dalam usahatani mangganya.

Faktor ekonomi lainnya yang mempengaruhi petani melakukan sistem tebasan yaitu kemampuan petani untuk menerima risiko. Kemampuan petani dalam menanggung risiko, bisa dilihat dari besar atau kecilnya pendapatan. Hal ini berarti semakin besar pendapatan petani, maka petani akan semakin berani untuk menerima risiko.

Apabila petani memiliki pekerjaan lainnya di luar usahatani mangga (non mangga), maka hal ini akan menambah pendapatan petani untuk menghidupi dia beserta keluarganya. Masalah lain yang perlu diperhatikan dalam jangka pendek maupun panjang, adalah apabila terjadi kondisi pendapatan petani dari mangga lebih kecil dari pendapatan non mangga, maka kondisi ini cenderung akan menimbulkan kekhawatiran dalam jangka waktu tertentu petani tidak termotivasi lagi untuk berusahatani mangga dan beralih ke non mangga. Semakin kecil pendapatan petani dari non mangga, maka petani semakin memilih sistem tebasan.

Berdasarkan uraian di atas, maka faktor sosial ekonomi yang mempengaruhi petani memilih sistem tebasan yaitu umur, pendidikan, 


\section{AIMBAR \\ Agribisnis}

ISSN 2460-4321

Volume 1・Nomor 2・Januari 2016

pengalaman, intensitas pemeliharan tanaman, hubungan ikatan sosial, luas lahan garapan, biaya produksi usahatani, ketersediaan tenaga kerja keluarga, kemampuan menerima risiko, ada tidaknya pendapatan petani dari usaha non mangga.

\section{METODE PENELITIAN}

Penelitian ini dilaksanakan di Desa Pasirmuncang, Kecamatan Panyingkiran, Kabupaten Majalengka.

Jenis data yang dikumpulkan mencakup data primer dan data sekunder. Data primer dikumpulkan melalui wawancara langsung dengan petani responden dan juga beberapa informan kunci (pedagang mangga, ketua gapoktan, kepala desa, dll) untuk memberikan gambaran umum. Data sekunder dikumpulkan melalui studi literatur pada beberapa referensi yang terkait.

Sampel pada penelitian ini adalah petani mangga tebasan yang diambil secara stratified random sampling sebanyak 30 orang. Tiga puluh orang responden dipilih dengan asumsi bahwa jumlah ini bisa memenuhi syarat untuk distribusi normal. Tiga puluh petani dipilih secara acak dari 63 anggota yang tercatat di daftar anggota gapoktan petani mangga di Desa Pasirmuncang. Sesuai dengan proporsi jumlah petani mangga yang terdaftar, 11 orang dipilih dari kategori petani mangga skala besar (mempunyai pohon mangga lebih dari 100 pohon), 8 orang dipilih dari kategori petani mangga skala sedang (mempunyai pohon mangga antara 50 sampai dengan 100 pohon), dan 11 orang dari karegori petani mangga skala kecil (mempunyai pohon mangga kurang dari 50 pohon).

Analisis Data

Untuk mengetahui faktor-faktor mempengaruhi petani dalam melakukan sistem tebasan dianalisis menggunakan metode regresi linier berganda, sebagai berikut :

$$
\mathrm{Y}=\beta_{0}+\beta_{1} \mathrm{X}_{1 \mathrm{i}}+\beta_{2} \mathrm{X}_{2 \mathrm{i}}+\ldots+\beta_{9} \mathrm{X}_{9 \mathrm{i}}+\delta \mathrm{i}
$$

Keterangan :

$\mathrm{Y}=$ Persentase pohon mangga yang ditebas

$\beta 0, \beta i(i=1 \ldots 9)=$ koefisien regresi

$\mathrm{X}_{1}=$ Umur petani mangga

$\mathrm{X}_{2}=$ Lama pendidikan formal petani (tahun)

$\mathrm{X}_{3}=$ Pengalaman melakukan penebasan (tahun)

$\mathrm{X}_{4}=$ luas lahan tebasan
$\mathrm{X}_{5}=$ Biaya Produksi (Rp/tahun). Biaya produksi ini adalah pengeluaran yang harus dibayar petani dari pengolahan tanah sampai menjelang panen.

$\mathrm{X}_{6}=$ Jumlah ketersediaan tenaga kerja keluarga (HKP)

$\mathrm{X}_{7}=$ Risiko harga (Persentase jumlah mangga yang dijual)

$\mathrm{X}_{8}=$ Pendapatan petani per tahun dari mangga (Rp/tahun).

$\mathrm{X}_{9}=$ Memiliki pekerjaan lain selain berusaha mangga $(1=$ memiliki pekerjaan lain, $0=$ tidak memiliki pekerjaan lain)

$\delta \mathrm{I}=$ Galat (error)

Konsep yang digunakan untuk pendapatan usahatani mangga adalah pendapatan bersih petani mangga dengan formulasi sebagai berikut:

$\pi=\mathrm{TR}-\mathrm{TC}$

$\mathrm{TR}=\mathrm{P} . \mathrm{Q}$

Keterangan :

$\pi=$ Pendapatan bersih

$\mathrm{TR}=$ Penerimaan

$\mathrm{TC}=$ Biaya total

$\mathrm{P}=$ Harga mangga

$\mathrm{Q}=$ Jumlah produksi mangga

Uji Durbin -Watson dipergunakan untuk menguji asumsi heteroskedastisitas dari data yang digunakan. Uji kolinearitas dengan menggunakan VIF juga digunakan untuk menguji asumsi bahwa tidak ada autokolinearitas antara berbagai variabel bebas yang dipergunakan dalam model. Uji Kolmogorov-Smirnov dipergunakan untuk menguji asumsi normalitas dari data yang dipergunakan.

\section{HASIL DAN PEMBAHASAN Deskripsi Petani Mangga}

Sub bab ini membahas deskripsi karakteristik petani mangga berdasarkan karakteristik sosial dan ekonominya. Selain berdasarkan rata-rata dari seluruh responden, pembahasan juga dilakukan dengan cara membandingkan petani berdasarkan skala usahataninya, yaitu: petani tebasan skala kecil (menebas $<50$ pohon), skala sedang (menebas 


\section{Kelembagaan Tataniaga dan Faktor Yang Mempengaruhi Petani Mangga \\ Memilih Sistem Tebasan}

DINI ROCHDIANI, SARA RATNA QANTI, ZUMI SAIDAH

50-100 pohon), dan skala besar (menebas $>100$ pohon).

Faktor-faktor sosial yang dibahas adalah umur, tingkat pendidikan formal, serta pengalaman melakukan tebasan. Faktor-faktor ekonomi yang dibahas adalah jumlah ketersediaan tenaga kerja dalam keluarga, jumlah pohon dan luas lahan yang dikelola dan ditebas, pendapatan petani dari mangga, memiliki pekerjaan lain selain usahatani mangga, biaya produksi, dan kemampuan menerima risiko.

\section{Umur, Pendidikan, dan Pengalaman Usahatani Mangga dan Menebas}

Berdasarkan hasil penelitian, rata-rata umur petani adalah 44 tahun. Berdasarkan skala usahanya, tidak ada perbedaan yang signifikan secara statistik dari ketiga stratifikasi. Petani yang berskala besar rata-rata relatif berusia muda jika dibandingkan dengan petani skala kecil dan menengah. Hal ini mengindikasikan bahwa sistem tebasan ini lebih banyak diadopsi oleh petani-petani yang lebih muda.

Dilihat dari tingkat pendidikan, maka ratarata pendidikan formal petani penebas adalah lulusan SD. Jika dilihat berdasarkan skala usahanya, tidak ada perbedaan yang signifikan antara rata-rata tingkat pendidikan di antara masing-masing kategorisasi penebas. Walaupun demikian, penebas skala besar relatif memiliki tingkat pendidikan yang lebih tinggi dibandingkan dengan penebas skala kecil dan menengah. Hal ini menunjukkan bahwa semakin tinggi tingkat pendidikannya, semakin tinggi untuk mengadopsi sistem tebasan mangga.

Selain faktor umur dan pendidikan, faktor lainnya seperti dari hasil analisis yang disajikan di Lampiran 1 menunjukkan bahwa rata-rata pengalaman usahatani petani penebas dalam berusahatani mangga adalah 13 tahun. Hal ini menunjukkan bahwa rata-rata petani memulai melakukan usahatani mangga di awal tahun 2000-an. Salah satu kemungkinan penyebab mengapa rata-rata petani memulai melakukan usahatani mangga di tahun 2000-an diperkirakan berhubungan dengan adanya program pemerintah bekerjasama dengan Jepang yang dinamakan "Program for Integrated Horticulture Development in Upland Areas" (IHDUA). Program ini dimulai tahun 1998 sampai dengan 2002 dan dilaksanakan di daerah sentra mangga, salah satunya adalah Majalengka. Selain dari adanya intervensi pemerintah, hal lain yang memungkinkan menjadi penyebab mengapa rata-rata petani memulai usahatani mangganya di tahun 2000an adalah dari sisi permintaan pasar terhadap mangga yang meningkat dan tingginya harga jual terutama untuk mangga Gedong gincu.

Berdasarkan skala petani tebasan, terdapat perbedaan yang signifikan antara rata-rata lamanya pengalaman usahatani mangga antar kategori. Rata-rata pengalaman petani penebas melakukan sistem tebasan sudah berlangsung selama 12 tahun. Petani penebas berskala besar relatif memiliki pengalaman melakukan sistem tebasan lebih lama (14 tahun) dibandingkan petani penebas skala sedang (13 tahun) dan skala kecil (9 tahun). Hal ini menunjukkan bahwa semakin lama seorang petani berusahatani mangga, semakin besar kemungkinannya untuk melakukan sistem tebasan.

\section{Mata Pencaharian}

Mata pencaharian yang dibahas dalam sub bab ini mencakup mata pencaharian dari usahatani mangga, usahatani lain non mangga, dan mata pencaharian di luar usahatani. Berdasarkan hasil penelitian, hampir seluruh responden (97\% dari responden) menyatakan bahwa usaha mangga adalah mata pencaharian utamanya. Terlebih untuk petani penebas yang berskala kecil dan sedang, semua responden menyatakan bahwa berusahatani mangga adalah mata pencaharian utama.

Meskipun hampir seluruh responden memiliki pencaharian utama sebagai petani mangga, ada $60 \%$ responden yang memiliki mata pencaharian tambahan baik dari sektor pertanian (misalnya mengusahakan komoditas lain seperti padi) maupun dari sektor non pertanian. Khusus untuk sektor non pertanian, ada $27 \%$ dari keseluruhan responden yang memiliki pekerjaan di luar sektor pertanian, misalnya seperti menjadi tukang ojeg, buruh pabrik, maupun wiraswasta (berdagang).

\section{Jumlah Ketersediaan Tenaga Kerja dalam Keluarga}

Hasil penelitian memperlihatkan bahwa rata-rata ketersediaan tenaga kerja dalam keluarga, yang ditunjukkan oleh banyaknya anggota keluarga yang berusia produktif (14-65 


\section{AIMBAR \\ Agribisnis}

ISSN 2460-4321

Volume 1 • Nomor 2 • Januari 2016

tahun), adalah 2 orang. Jika dilihat berdasarkan kategori skala usahanya, terdapat perbedaan rata-rata yang signifikan untuk setiap kategori. Petani yang skala usahanya sedang memiliki rata-rata jumlah tenaga kerja dalam keluarga (TKDK) yang lebih tinggi (3 orang) dibandingkan petani penebas dengan kategori kecil atau besar (2 orang). Hal ini memberikan indikasi bahwa ada hubungan kuadratik antara jumlah TKDK dan intensitas penebasan (skala usaha) yang dilakukan oleh petani.

\section{Risiko}

Berdasarkan Lampiran 1, dapat dilihat bahwa secara keseluruhan hanya $20 \%$ petani yang mampu/berani mengambil risiko. Secara statistik, terlihat adanya perbedaan yang signifikan antara petani yang berskala usaha besar dengan petani yang berskala usaha kecil dan sedang. Separuh $(60 \%)$ dari petani yang berskala usaha besar berani menerima risiko sedangkan petani skala sedang dan kecil tidak berani berani mengambil risiko. Temuan ini menjadi indikasi bahwa faktor risiko bisa mempengaruhi petani dalam memilih sistem tebasan dalam usahatani mangga. Semakin mampu menerima risiko, maka petani cenderung semakin memilih sistem tebasan.

\section{Luas Lahan, Jumlah Pohon, Varietas Mangga, Produktivitas, dan Intensitas Tanam (Pemeliharaan dan Penggunaan Teknologi)}

Lampiran 2 menunjukkan bahwa rata-rata luas lahan yang dikelola petani mangga adalah 2,2 hektar. Jika dibandingkan dengan man-land ratio di Desa Pasirmuncang (sebesar 7,9 yang berarti bahwa satu hektar dikuasai oleh sekitar 8 orang atau setiap satu orang menguasai 0.13 ha lahan), maka petani mangga dapat dikategorikan sebagai orang yang menguasai lahan lebih besar dari rata-rata penguasaan lahan oleh masyarakat Desa Pasirmuncang.

Berdasarkan stratifikasi skala usahanya, terdapat perbedaan yang signifikan secara statistik dalam hal luas penguasaan lahan antara petani yang berskala usaha besar dan petani yang berskala usaha kecil. Petani berskala usaha besar memiliki rata-rata penguasaan lahan 4,7 hektar, sementara petani berskala kecil hanya rata-rata menguasai lahan 0,5 hektar. Jika dilihat dari hasil analisis statistik, terdapat hubungan berbanding lurus antara luas lahan yang dikelola dan luas lahan yang ditebas. Hasil analisis menunjukkan bahwa semakin luas lahan yang dimiliki, semakin luas juga persentase lahan yang diusahakan untuk tebasan. Kedua hal ini mengindikasikan bahwa ada hubungan positif antara luas lahan yang dikelola dengan pemilihan sistem tebasan yang dilakukan oleh petani.

Berdasarkan jumlah pohon yang dikelola, rata-rata petani mengelola 220 pohon mangga, dan yang diusahakan melalui tebasan 181 pohon. Bila dilihat dari masing-masing skala usaha, maka secara analisis statistik terdapat perbedaan yang signifikan antara petani berskala usaha besar dan petani berskala usaha kecil. Petani berskala usaha besar mengelola rata-rata 481 pohon mangga dan 424 pohon diusahakan melalui tebasan. Petani berskala usaha kecil mengelola rata-rata 50 pohon mangga, dan 21 pohon untuk tebasan. Petani berskala usaha besar memiliki persentase jumlah pohon tebasan yang lebih besar $(88 \%)$ dari persentase jumlah pohon yang dimilikinya. Sementara itu, petani yang berskala usaha kecil, memiliki persentase jumlah pohon tebasan yang lebih kecil $(42 \%)$ daripada persentase jumlah pohon yang dimilikinya.

Berdasarkan varietas mangga yang dikelola, rata-rata petani mengusahakan mangga Gedong Gincu (53\%) diikuti dengan Harumanis (29\%), Dermayu (15\%) dan mangga varietas lainnya (3\%). Tidak terdapat perbedaan yang signifikan secara statistik antara masingmasing strata petani. Namun demikian, secara persentase dari total pohon yang dikelola untuk masing-masing strata, terdapat kecenderungan bahwa petani berskala usaha kecil mengelola varietas Gedong Gincu lebih besar (59\% dari total pohon yang dikelola) dari skala sedang (48\% dari total pohon yang dikelola) dan besar (51\% dari total pohon yang dikelola). Petani berskala sedang lebih mengelola varietas Dermayu (21\% dari total pohon yang dikelola) dengan persentase lebih besar daripada petani skala kecil dan besar. Petani skala besar lebih mengelola varietas Harumanis (36\% dari total pohon yang dikelola) dengan perentase lebih besar daripada petani kecil dan sedang.

Kualitas dan jumlah produksi mangga dipengaruhi oleh intensitas tanam yang dilakukan petani. Level intensitas tanam yang 


\section{Kelembagaan Tataniaga dan Faktor Yang Mempengaruhi Petani Mangga \\ Memilih Sistem Tebasan}

DINI ROCHDIANI, SARA RATNA QANTI, ZUMI SAIDAH

dimaksud dalam penelitian ini berhubungan dengan tingkat perawatan dan pemberian input (saprodi seperti pupuk, hormon tumbuh dan pestisida) terhadap pohon mangga yang dilakukan oleh petani. Berdasarkan hasil analisis yang disajikan di Lampiran 2, dapat diperoleh hasil bahwa tingkat perawatan dan pemberian saprodi untuk tanaman mangga yang dikelola oleh petani, sangat tinggi mencapai rata-rata $92 \%$. Hasil analisis secara statistik tidak menunjukkan adanya perbedaan yang signifikan antara strata petani dalam tingkat intensitas tanamnya, akan tetapi petani yang berskala usaha besar meiliki level intensitas yang paling tinggi (93\%), diikuti oleh petani berskala kecil (92\%) dan petani berskala sedang (89\%). Hal ini menunjukkan bahwa intensifikasi pada tanaman mangga sudah dilakukan dengan sangat baik melalui perawatan, pemberian pupuk, pengaplikasian pestisida, dan juga pengaplikasian hormon tumbuh yang merupakan salah satu upaya untuk membuat pohon mangga berbuah di luar musimnya atau dapat berbuah lebih cepat dengan kualitas dan jumlah produksi yang baik. Temuan ini sesuai dengan hasil penelitian Qanti (2014), dimana $69 \%$ petani sudah mengaplikasikan pupuk, 39\% petani sudah mengaplikasikan pestisida, $28 \%$ petani sudah menggunakan hormon tumbuh, dan $45 \%$ petani melakukan pemangkasan sebagai salah satu bentuk perawatan terhadap pohon mangga yang mereka kelola.

Total produksi rata-rata yang dihasilkan petani adalah sekitar 19 ton per tahun dari seluruh pohon yang dikelola. Berdasarkan produktivitas per pohonnya, ternyata produktivitasnya masih rendah, yaitu 0.16 ton/pohon/tahun. Nilai ini jauh lebih rendah dari produktivitas ideal pohon mangga (berumur lebih dari 10 tahun), yaitu 0.5 ton/pohon/tahun (Rebin, Karsinah, Soemargono, 2008).

\section{Biaya Produksi dan Pendapatan Petani}

Rata-rata biaya total produksi mangga per tahun adalah sekitar Rp. 78. 000.000,- . Dilihat dari skala usaha petani penebasnya, terdapat perbedaan yang signifikan antara biaya total yang dikeluarkan oleh petani penebas. Semakin besar skala usahatani petani, semakin besar biaya produksi yang dikeluarkan. Hal ini sesuai dengan logika karena semakin banyak pohon yang diusahakan maka semakin banyak biaya total yang harus dikeluarkan. Akan tetapi jika kita lakukan kontrol terhadap jumlah pohon dengan menghitung biaya produksi rata-rata per pohon, hasil analisis menunjukkan bahwa ratarata biaya yang dikeluarkan oleh petani untuk biaya produksi adalah sekitar Rp 600.000,/pohon/tahun dan tidak ada perbedaan yang signifikan antar strata. Walaupun demikian, hasil analisis menunjukkan bahwa petani penebas skala sedang mengeluarkan biaya ratarata per pohon hampir dua kali lipat lebih besar dari pada petani yang berskala kecil maupun dari petani yang berskala besar.

Pendapatan yang diperoleh petani dari usahatani mangga secara rata-rata adalah $\mathrm{Rp}$. 102.000.000,-/tahun. Rata-rata pendapatan per tahun berdasarkan skala usaha petani adalah sebagai berikut: petani skala kecil sekitar Rp 26 juta rupiah/tahun, petani skala sedang sekitar Rp 48.000.000,-/tahun, dan petani skala besar Rp 219.000.000,-/tahun. Jika dilakukan kontrol terhadap jumlah pohon yang dikelola, diperoleh rata-rata pendapatan petani per pohon per tahun adalah Rp 490.000,-.

\section{Faktor-Faktor yang Mempengaruhi Petani Mangga Melakukan Sistem Tebasan}

Sebelum analisis regresi, pengujian dilakukan terhadap data untuk mengetes asumsi heteroskedastisitas, autokorelasi, dan normalitas. Berdasarkan hasil uji DurbinWatson, diperoleh bahwa tidak ditemukan adanya heteroskedastisitas dalam data dan variabel yang digunakan. Berdasarkan uji kolinearitas menggunakan VIF, diperoleh nilai VIF di bawah 10 sehingga diperoleh kesimpulan bahwa tidak terdapat kolineritas antar variabel yang digunakan dalam model. Berdasarkan uji Kolmogorov-Smirnov, diperoleh kesimpulan bahwa data yang digunakan sudah memenuhi asumsi distribusi normal.

Berdasarkan hasil analisis statistik dengan menggunakan regresi multivariate secara linear, diperoleh hasil seperti yang terlihat di Tabel 1 sebagai berikut: 


\section{AIMBAR \\ Agribisnis \\ ISSN 2460-4321}

Volume 1・Nomor 2・Januari 2016

Tabel 1. Pendugaan Fungsi Faktor Sosial Ekonomi yang Mempengaruhi Petani Mangga Melakukan Sistem Tebasan

\begin{tabular}{cccc}
\hline Variabel & Koef & Se & p \\
\hline Konstanta & 66.91 & 41.73 & 0.13 \\
$\mathrm{X}_{1}$ & -1.29 & 0.59 & 0.04 \\
$\mathrm{X}_{2}$ & 1.41 & 2.02 & 0.49 \\
$\mathrm{X}_{3}$ & 1.49 & 1.09 & 0.19 \\
$\mathrm{X}_{4}$ & 25.34 & 11.16 & 0.03 \\
$\mathrm{X}_{5}$ & 0.01 & 0.01 & 0.07 \\
$\mathrm{X}_{6}$ & 0.01 & 0.01 & 0.33 \\
$\mathrm{X}_{7}$ & 5.56 & 8.96 & 0.09 \\
$\mathrm{X}_{8}$ & 1.79 & 1.08 & 0.16 \\
$\mathrm{X}_{9}$ & 11.91 & 13.76 & 0.25 \\
\hline
\end{tabular}

Keterangan:

Y Persentase luas lahan tebasan dari Total luas lahan yang dikelola (\%)

X1 Umur responden (tahun)

$\mathrm{X} 2$ Lamanya pendidikan formal (tahun)

X3 Lamanya pengalaman berusahatani (tahun)

X4 Memiliki pekerjaan lain selain usahatani mangga (bisa usahatani lain selain mangga ataupun dari sektor non pertanian)

X5 Pendapatan rata-rata dari mangga setahun lalu (Rp/pohon/tahun)

X6 Biaya rata-rata per pohon (Rp/pohon/tahun)

X7 Jumlah tenaga kerja dalam keluarga (orang)

X8 Total luas lahan yang dikelola (Ha)

X9 Memiliki kemampuan untuk mengatasi risiko

\section{KESIMPULAN DAN SARAN \\ Kesimpulan}

1. Karakteristik petani mangga yang memilih sistem tebasan rata-rata berumur 44 tahun dengan rata-rata pendidikan formal adalah lulusan sekolah dasar serta pengalaman berusahatani mangga rata-rata 13 tahun dan rata-rata mereka bersifat risk averse (penghindar risiko). Kondisi ini terjadi karena modal untuk usahatani mangga memerlukan modal besar dan menghadapi fluktuasi harga yang sangat tajam sebagai risiko harga.

2. Secara serempak faktor pendidikan, pengalaman, luas lahan, biaya produksi, ketersediaan tenaga kerja dalam keluarga, kemampuan petani menanggung risiko, pendapatan petani dari mangga, dan pendapatan petani dari pekerjaan lainnya) mempengaruhi petani mangga untuk memilih sistem tebasan.

3. Secara parsial, faktor umur petani dan faktor memiliki pekerjaan di luar usahatani mangga mempengaruhi secara negatif terhadap pemilihan sistem tebasan oleh petani mangga. Semakin bertambah umur petani (semakin tua), semakin petani tidak memiliki pekerjaan di luar usahatani mangga, dan semakin besar pendapatan ratarata per pohon yang diperoleh oleh petani dari mangga tebasan, maka semakin petani memilih sistem tebasan. Faktor yang paling dominan mempengaruhi pemilihan sistem tebasan oleh petani adalah tidak adanya pekerjaan lain di luar usahatani mangga. Hal ini berarti bahwa pendapatan dari mangga dengan sistem tebasan dapat memenuhi kebutuhan petani dan keluarganya atau sistem tebasan mangga memberikan keuntungan bagi petani.

\section{Saran}

1. Petani perlu diberikan bantuan modal untuk usahatani mangga agar produktivitasnya bisa mendekati produktivitas ideal $(0.5$ ton/pohon/tahun) karena saat ini produktivitas petani masih pada kondisi ratarata 0.19 ton/pohon/tahun.

2. Petani perlu memperkuat kelembagaan petani (kelompok tani) untuk memperkuat posisi tawar dalam penentuan harga mangga. Saat ini harga masih ditentukan oleh pembeli (pedagang pengumpul/bandar).

3. Perlu menambahkan variabel-variabel penelitian lain dalam mencari faktor-faktor yang paling mendekati untuk petani memilih sistem tebasan karena dalam penelitian ini, secara parsial, hanya ada tiga variabel yang paling berpengaruh. Hal ini menunjukkan bahwa masih ada variabel lain yang mempengaruhi pemilihan sistem tebasan, tetapi belum dimasukkan ke dalam penelitian ini. 


\section{Kelembagaan Tataniaga dan Faktor Yang Mempengaruhi Petani Mangga \\ Memilih Sistem Tebasan \\ DINI ROCHDIANI, SARA RATNA QANTI, ZUMI SAIDAH}

\section{DAFTAR PUSTAKA}

Natawidjaja et al., 2012. Understanding How Informality Works in Reality: The Case of Horticulture Sector in Indonesia. Paper presented at Meeting Small-Scale Farmers in Their Markets: Understanding and Improving the Institutions and Governance of Informal Agrifood Tradeheld in Amsterdam November 29-30, 2012.

Qanti, Sara Ratna. 2014. Determinants of Mango Farmer Choices of Modern Versus Traditional Market Channel and Farm Technology Intensification In Java Indonesia. Thesis. Michigan State University, USA.

Rebin, Karsinah, Soemargono. 2008. Peningkatan Produktivitas dan Kualitas Mangga Komersial Indonesia Melalui Pemuliaan dan Pengelolaan Tanaman. Balai Penelitian Buah Tropika, Badan Penelitian dan Pengembangan Pertanian Kementrian Pertanian.

World Bank. 2008. World Development Report: Agriculture for Development. 


\section{AIMBAR \\ Agribisnis}

ISSN 2460-4321

Volume 1 • Nomor 2 • Januari 2016

\section{LAMPIRAN}

Lampiran 1. Karakteristik Petani Penebas Mangga di Majalengka Tahun 2014, Berdasarkan Skala Usaha

\begin{tabular}{|c|c|c|c|c|c|}
\hline & & $\begin{array}{c}\text { Penebas } \\
\text { Kecil } \\
(<50 \text { pohon }) \\
n=11\end{array}$ & $\begin{array}{c}\text { Penebas } \\
\text { Sedang (50- } \\
100 \text { pohon) } \\
\\
n=8\end{array}$ & $\begin{array}{c}\text { Penebas } \\
\text { Besar } \\
(>100 \\
\text { pohon) } \\
\mathrm{n}=11\end{array}$ & $\mathrm{~N}=30$ \\
\hline 1 & $\begin{array}{l}\text { Karakteristik Petani: } \\
\text { Kependudukan }\end{array}$ & & & & \\
\hline 1.1 & $\begin{array}{l}\text { Jumlah orang dewasa (14-64 tahun) } \\
\text { dalam keluarga (orang) }\end{array}$ & $1.8^{\mathrm{a}}$ & $2.9^{\mathrm{b}}$ & $2.3^{\mathrm{a}, \mathrm{b}}$ & 2.2 \\
\hline 1.2 & Jumlah tanggungan keluarga (orang) & 2.6 & 2.9 & 3.2 & 2.9 \\
\hline 1.3 & Usia responden (tahun) & 46 & 46 & 40 & 44 \\
\hline 2 & Pendidikan & & & & \\
\hline 2.1 & $\begin{array}{l}\text { Lama mengenyam pendidikan formal } \\
\text { (tahun) }\end{array}$ & 7 & 6 & 9 & 7 \\
\hline $\begin{array}{r}2.2 \\
3\end{array}$ & $\begin{array}{l}\text { Pernah mengikuti pelatihan } \\
\text { Mata pencaharian }\end{array}$ & $42 \%$ & $43 \%$ & $18 \%$ & $33 \%$ \\
\hline 3.1 & $\overline{\text { Usahatani mangga }}$ & $100 \%$ & $100 \%$ & $91 \%$ & $97 \%$ \\
\hline 3.2 & $\begin{array}{l}\text { Memiliki pekerjaan di luar sektor } \\
\text { pertanian }\end{array}$ & $17 \%$ & $43 \%$ & $27 \%$ & $27 \%$ \\
\hline 3.3 & $\begin{array}{l}\text { Memiliki pekerjaan non mangga } \\
\text { (usahatani lain + non pertanian) }\end{array}$ & $58 \%$ & $43 \%$ & $72 \%$ & $60 \%$ \\
\hline 4 & Pengalaman Usahatani & & & & \\
\hline 4.1 & Pengalaman usahatani mangga (tahun) & $10.2^{\mathrm{a}}$ & $10.6^{\mathrm{a}, \mathrm{b}}$ & $17^{\mathrm{b}}$ & 12.8 \\
\hline 4.2 & Pengalaman menebas mangga (tahun) & 8.6 & 13.1 & 14 & 11.7 \\
\hline 5 & $\begin{array}{l}\text { Berani mengambil risiko }(1=\text { Ya, } \\
0=\text { Tidak })\end{array}$ & $0^{\mathrm{a}}$ & $0^{\mathrm{a}}$ & $50 \%{ }^{\mathrm{b}}$ & $20 \%$ \\
\hline
\end{tabular}




\section{Lampiran 2. Karakteristik Usahatani Petani Penebas Mangga di Majalengka Tahun 2014,} Berdasarkan Skala Usaha

\begin{tabular}{|c|c|c|c|c|c|}
\hline & & 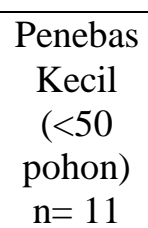 & $\begin{array}{c}\text { Penebas } \\
\text { Sedang } \\
(50-100 \\
\text { pohon) } \\
n=8\end{array}$ & $\begin{array}{c}\text { Penebas } \\
\text { Besar } \\
(>100 \\
\text { pohon) } \\
n=11\end{array}$ & $\mathrm{~N}=30$ \\
\hline 1 & $\begin{array}{l}\text { Karakteristik Usahatani: } \\
\text { Jumlah pohon }\end{array}$ & & & & \\
\hline 1.1 & Total pohon yang dikelola (pohon) & $49.9^{\mathrm{a}}$ & $102.7^{\mathrm{a}, \mathrm{b}}$ & $481.2^{\mathrm{b}}$ & 220.4 \\
\hline 1.1 .1 & Total Gedong Gincu yang dikelola (pohon) & $28.8^{\mathrm{a}}$ & $52.3^{\mathrm{a}, \mathrm{b}}$ & $212^{\mathrm{b}}$ & 101.5 \\
\hline 1.1 .2 & Total Harumanis yang dikelola (pohon) & 12 & 28.7 & 225.8 & 97.1 \\
\hline 1.1 .3 & $\begin{array}{l}\text { Total Cengkir/Dermayu yang dikelola } \\
\text { (pohon) }\end{array}$ & $7^{\mathrm{a}}$ & $21.6^{\mathrm{a}, \mathrm{b}}$ & $41.5^{\mathrm{b}}$ & 23.1 \\
\hline 1.1 .4 & Total varietas lainnya yang dikelola (pohon) & 3 & 0.1 & 1.8 & 1.9 \\
\hline 1.1 .5 & $\begin{array}{l}\text { Persentase Gedong Gincu yang dikelola } \\
\text { (pohon) }\end{array}$ & $59 \%$ & $48 \%$ & $51 \%$ & $53 \%$ \\
\hline 1.1.6 & Persentase Harumanis yang dikelola (pohon) & $22 \%$ & $32 \%$ & $36 \%$ & $29 \%$ \\
\hline 1.1.7 & $\begin{array}{l}\text { Persentase Cengkir/Dermayu yang dikelola } \\
\text { (pohon) }\end{array}$ & $15 \%$ & $21 \%$ & $11 \%$ & $15 \%$ \\
\hline 1.1 .8 & $\begin{array}{l}\text { Persentase varietas lainnya yang dikelola } \\
\text { (pohon) }\end{array}$ & $5 \%$ & $0.1 \%$ & $1 \%$ & $3 \%$ \\
\hline 1.2 & Total pohon yang dimiliki (pohon) & 30 & 29 & 57 & 40 \\
\hline 1.2 .1 & Total Gedong Gincu yang dimiliki (pohon) & 21 & 26 & 34 & 27 \\
\hline 1.2 .2 & Total Harumanis yang dimiliki (pohon) & 4 & 2 & 19 & 9 \\
\hline 1.2 .3 & $\begin{array}{l}\text { Total Cengkir/Dermayu yang dimiliki } \\
\text { (pohon) }\end{array}$ & 5 & 3 & 4 & 4 \\
\hline 1.2 .4 & Total varietas lainnya yang dimiliki (pohon) & 3 & 0 & 0 & 1 \\
\hline 1.3 & Total pohon tebasan (pohon) & $21^{\mathrm{a}}$ & $74^{\mathrm{a}, \mathrm{b}}$ & $424^{\mathrm{b}}$ & 181 \\
\hline 1.3 .1 & Total Gedong Gincu yang tebasan (pohon) & $9.2^{\mathrm{a}}$ & $27.9^{\mathrm{a}, \mathrm{b}}$ & $177.5^{\mathrm{b}}$ & 75.3 \\
\hline 1.3 .2 & Total Harumanis yang tebasan (pohon) & 7.3 & 27.6 & 206.6 & 85.1 \\
\hline 1.3 .3 & Total Cengkir/Dermayu yang tebasan (pohon) & $2 \mathrm{a}$ & $18 \mathrm{a}, \mathrm{b}$ & $38 b$ & 19 \\
\hline 1.3 .4 & Total varietas lainnya yang tebasan (pohon) & 0.3 & 0 & 1.8 & 0.8 \\
\hline 1.4 & $\begin{array}{l}\text { Persentase total pohon mangga yang ditebas } \\
\text { dari total pohon mangga yang dikuasai }\end{array}$ & $48 \%{ }^{\mathrm{a}}$ & $78 \%^{\mathrm{b}}$ & $85 \%^{\mathrm{b}}$ & $69 \%$ \\
\hline 1.4 .1 & $\begin{array}{l}\text { Persentase Gedong Gincu yang ditebas dati } \\
\text { total Gedong Gincu yang dikuasai }\end{array}$ & $46 \%$ & $59 \%$ & $80 \%$ & $61 \%$ \\
\hline 1.4 .2 & $\begin{array}{l}\text { Persentase Harumanis yang ditebas dati total } \\
\text { Harumanis yang dikuasai }\end{array}$ & $50 \%{ }^{\mathrm{a}}$ & $94 \%^{\mathrm{b}}$ & $86 \%^{\mathrm{b}}$ & $74 \%$ \\
\hline 1.4 .3 & $\begin{array}{l}\text { Persentase Dermayu yang ditebas dati total } \\
\text { Dermayu yang dikuasai }\end{array}$ & $37 \%^{\mathrm{a}}$ & $79 \%^{\mathrm{b}}$ & $82 \%^{\mathrm{b}}$ & $63 \%$ \\
\hline 1.4 .4 & $\begin{array}{l}\text { Persentase Lainnya yang ditebas dati total } \\
\text { Lainnya yang dikuasai }\end{array}$ & $17 \%$ & $0 \%$ & $9 \%$ & $10 \%$ \\
\hline 1.4 .5 & $\begin{array}{l}\text { Persentase Gedong Gincu yang ditebas dari } \\
\text { total pohon yang dikuasai }\end{array}$ & $25 \%$ & $28 \%$ & $41 \%$ & $32 \%$ \\
\hline 1.4 .6 & $\begin{array}{l}\text { Persentase Harumanis yang ditebas dari total } \\
\text { pohon yang dikuasai }\end{array}$ & $13 \%$ & $31 \%$ & $33 \%$ & $24 \%$ \\
\hline 1.4 .7 & $\begin{array}{l}\text { Persentase Dermayu yang ditebas dari total } \\
\text { pohon yang dikuasai }\end{array}$ & $6 \%{ }^{\mathrm{a}}$ & $19 \%^{\mathrm{b}}$ & $10 \%$ & $10 \%$ \\
\hline 1.4.8 & $\begin{array}{l}\text { Persentase varietas Lain yang ditebas dari } \\
\text { total pohon yang dikuasai }\end{array}$ & $2 \%$ & $0 \%$ & $1 \%$ & $1 \%$ \\
\hline
\end{tabular}




\section{MIMBAR \\ Agribisnis}

ISSN 2460-4321

Volume 1・ Nomor 2 • Januari 2016

Lampiran 2. (lanjutan)

\begin{tabular}{|c|c|c|c|c|c|}
\hline & & $\begin{array}{c}\text { Penebas } \\
\text { Kecil } \\
(<50 \\
\text { pohon }) \\
n=11\end{array}$ & $\begin{array}{c}\text { Penebas } \\
\text { Sedang } \\
(50-100 \\
\text { pohon }) \\
n=8\end{array}$ & $\begin{array}{c}\text { Penebas } \\
\text { Besar } \\
(>100 \\
\text { pohon }) \\
\mathrm{n}=11 \\
\end{array}$ & $\mathrm{~N}=30$ \\
\hline 2 & Luas Lahan: & & & & \\
\hline 2.1 & $\overline{\text { Luas lahan yang dikuasai (ha) }}$ & $0.5^{\mathrm{a}}$ & $1.5^{\mathrm{a}, \mathrm{b}}$ & $4.7^{\mathrm{b}}$ & 2.2 \\
\hline 3.1 & $\begin{array}{l}\text { Pendapatan rata-rata petani mangga per pohon } \\
\text { (Juta rupiah/tahun/pohon) }\end{array}$ & 0.56 & 0.46 & 0.45 & 0.49 \\
\hline 3.2 & $\begin{array}{l}\text { Pendapatan total petani penebas mangga per } \\
\text { tahun (Juta rupiah/tahun) }\end{array}$ & 25.8 & 47.7 & 219 & 102 \\
\hline 4 & Biaya Produksi & & & & \\
\hline 4.1 & Biaya per pohon (Juta Rp/pohon/tahun) & 0.47 & 0.95 & 0.49 & 0.59 \\
\hline 4.2 & Biaya total (Juta Rp/tahun) & $18.6^{\mathrm{a}}$ & $92.5^{\mathrm{a}, \mathrm{b}}$ & $103,3^{\mathrm{b}}$ & 77.8 \\
\hline \multirow[t]{2}{*}{5} & $\underline{\text { Level intensitas tanam }}$ & & & & \\
\hline & $\begin{array}{l}\text { Tingkat perawatan dan pemberian saprotan } \\
\text { terhadap pohon mangga }(\%)\end{array}$ & $92 \%$ & $89 \%$ & $93 \%$ & $92 \%$ \\
\hline 6 & Produktivitas Pohon & & & & \\
\hline 6.1 & Total produksi (ton/tahun) & $9.9^{\mathrm{a}}$ & $13.8^{\mathrm{a}}$ & $30.9^{\mathrm{b}}$ & 18.5 \\
\hline 6.2 & Produktivitas pohon (ton/pohon/tahun) & 0.19 & 0.15 & 0.14 & 0.16 \\
\hline 7 & $\frac{\text { Harga Tebasan }}{\text { (dari yg menebas varietas ini) }}$ & & & & \\
\hline 7.1 & $\begin{array}{l}\text { Harga tebasan untuk varietas Gedong Gincu } \\
\text { (ribu Rp/pohon) }\end{array}$ & 520 & 617 & 540 & 549 \\
\hline 7.2 & $\begin{array}{l}\text { Harga tebasan untuk varietas Harumanis (ribu } \\
\text { Rp/pohon) }\end{array}$ & 225 & 307 & 276 & 266 \\
\hline 7.3 & $\begin{array}{l}\text { Harga tebasan untuk varietas Cengkir/Dermayu } \\
\text { (ribu Rp/pohon) }\end{array}$ & 194 & 307 & 244 & 246 \\
\hline 7.4 & $\begin{array}{l}\text { Harga tebasan untuk varietas lainnya (ribu } \\
\text { Rp/pohon) } \\
\text { (dari keseluruhan responden) }\end{array}$ & 75 & 0 & 0 & 50 \\
\hline 7.5 & $\begin{array}{l}\text { Harga tebasan untuk varietas Gedong Gincu } \\
\text { (ribu Rp/pohon) }\end{array}$ & 433 & 529 & 540 & 495 \\
\hline 7.6 & $\begin{array}{l}\text { Harga tebasan untuk varietas Harumanis (ribu } \\
\text { Rp/pohon) }\end{array}$ & 186 & 307 & 276 & 248 \\
\hline 7.7 & $\begin{array}{l}\text { Harga tebasan untuk varietas Cengkir/Dermayu } \\
\text { (ribu Rp/pohon) }\end{array}$ & 129 & 307 & 222 & 205 \\
\hline 7.8 & $\begin{array}{l}\text { Harga tebasan untuk varietas lainnya (ribu } \\
\text { Rp/pohon) }\end{array}$ & 13 & 0 & 0 & 5 \\
\hline 8. & Menerima bantuan modal & & & & \\
\hline 8.1 & $\begin{array}{l}\text { Persentase besarnya bantuan modal dari } \\
\text { keseluruhan biaya (bagi yg menerima) }\end{array}$ & $\begin{array}{l}65 \% a \\
(n=2)\end{array}$ & $\begin{array}{l}8.5 \% b \\
(n=2)\end{array}$ & $\stackrel{-}{-}$ & $\begin{array}{l}37 \% \\
(\mathrm{n}=4)\end{array}$ \\
\hline 8.2 & $\begin{array}{l}\text { Persentase besarnya bantuan modal dari } \\
\text { keseluruhan biaya (dari keseluruhan responden) }\end{array}$ & $11 \%$ & $2.5 \%$ & 0 & $5 \%$ \\
\hline
\end{tabular}

